\title{
The Effect of Inquiry Model on Teacher's Self Controlling in Class X Virus in SMA Private Vocational School UISU Medan
}

\author{
Zul Aida \\ Faculty of Teachers Training and Education, North Sumatera Islamic University, Medan, 20217, Indonesia \\ zul.aida@fkip.uisu.ac.id \\ Corresponding Author: zeinor.spd@gmail.com | Phone : +6281375415242
}

\begin{abstract}
This study aims to determine the effect of the Inquiry learning model on student learning outcomes in class $\mathrm{X}$ virus material in UISU Medan Private High School. The research method uses descriptive research methods and types of correlational research to see if there is an effect of using the inquiry model on self-controlling teachers with a research sample of 2 classes that were randomly assigned using cluster random sampling technique. In class X-1 they are taught the guided inquiry learning model, and class X-2 is taught using the conventional learning model. The instrument used in this study was a test of critical thinking skills in the form of a written test. The data analysis technique uses correlation regression. Based on the calculation, it is found that there is an influence in the use of the Inquiry Model on Teacher Self-Controlling with a value of $r=0.43$, in the value of Covariate Analysis using SPSS, namely $55.20 \pm 15.65$, which is significantly greater than the class control that is equal to $50.10 \pm 11.44$. The results of the analysis show that there is a significant influence in the use of the Inquiry model on Teacher Self-Controlling at the real level $\alpha=0.05$.

Keywords: Inquiry Model; Teacher Self Controlling; Virus Matery
\end{abstract}

\section{Introduction}

The problem that is often faced in the world of education is the learning process. The learning process continues to develop as technology, civilization, techniques, models, adaptations are faced and take place continuously in school. When the learning process has gone well, it still has to be controlled or seen both the supporting factors and the impacts that occur or the effects obtained in the results of the learning process. The results obtained can increase or decrease, both in terms of students and in terms of educators (teachers) themselves. The use of traditional and conventional learning models is still being implemented as a basic reference in developing the learning process or model. High School Biology Science Learning is an interesting lesson and is one of the favorite subjects of high school students based on survey results in general. However, even if the teacher does not have the teaching ability or competence, it is not impossible that the learning process of Biology Science in SMA becomes boring, uninteresting, and monotonous. Inquiry learning is basically a way of solving real problems that come from individuals in a group by fostering student skills, making students independent, increasing student self-confidence and opening students' mindsets so that they are able to develop their abilities.

Inquiry learning is useful for inviting and teaching students so that students are active in the learning process through real experiences. The inquiry model makes students more active in finding and finding solutions to the problems given to them. For groups of students who are taught using traditional learning, the learning process tends to be teacher-centered using the lecture method. During the learning process, students' critical thinking skills are less developed, because students learn more individually by receiving, taking notes, and memorizing the subject matter they receive from the teacher as a determinant of the learning process. Inquiry Learning Model can provide development to students and teachers themselves. Teacher behavior can be assessed from the ability to orient to problems, formulate problems, formulate hypotheses, collect data, test hypotheses, and formulate conclusions. These stages are very similar and form a basic reference in the formulation of scientific work. This makes the basic thing for the teacher himself in controlling himself in being scientific about the Biology science learning material that he teachers. 


\section{Methods}

\subsection{Research Location}

The location of the study was conducted SMA SWASTA UISU MEDAN. The study was conducted from February to March 2020.

\subsection{Population and Sample}

The population in this study were 3 class X SMA Private UISU Medan. The sample used in this study were 2 classes which were determined randomly by using cluster random sampling technique. Randomization was carried out by lottery from 3 classes, so that class X-1 was obtained as the first experimental class that was taught using the guided inquiry learning model and X-2 as the control class that was taught using conventional learning to obtain the data needed in the study.

\subsection{Research Design}

In this, data collection techniques are carried out using instruments to measure the value of the Teacher's Self-Controlling level in the form of a questionnaire. . And the data analysis technique used is descriptive analysis technique, data normality prerequisite test, data homogeneity prerequisite test and hypothesis test

\subsection{Data Analysis Techniques}

The stages carried out in the analysis of research data are as follows:

1. Present data in the form of frequency distribution tables and histograms. Furthermore, from each research data it is determined by the values - the maximum, minimum, average, standard deviation, variance, mode and median values.

2. Testing the data analysis requirements before testing the research hypothesis. The requirements for the analysis are (a) Testing the normality of the data by using the error normality test for estimating the dependent variable on the independent variable, the test used is the Lileofors test. The test criterion is to accept the estimated error of the dependent variable with a normal distribution to the independent variable, if Lo $>\mathrm{L}$ table at a significant level $\mathrm{a}=0.05$ with $\mathrm{dk}=\mathrm{n}(\mathrm{b})$ Homogeneity test of variance with the Barlet test. The test criteria are to accept $\mathrm{Y}$ variance over $\mathrm{X}$, homogeneous if $\mathrm{X} 2 \mathrm{~h}>\mathrm{X} 2$ table, the significant level $\mathrm{a}=0.05$ with $\mathrm{dk}=\mathrm{k}-1$ (c) Testing on the linearity of the regression and the meaning of the linear regression coefficient, was carried out with Anava. The test criteria are, accept the regression model $\mathrm{Y}$ on $\mathrm{X}$, if $\mathrm{F}$ count $>\mathrm{F}$ table, and accept the linear regression coefficient means, if $\mathrm{F}$ count $<\mathrm{F}$ table.

3. Test the research hypothesis.

After all the testing requirements for data analysis have been met, the next step is to test the hypothesis

\section{Results And Discussions}

The results of data processing show that the self controlling variable has a minimum score of 76; maximum score 120; an average score of 96.53; mode 90; median 95, standard deviation 7.82 and variance 61.18..

Based on the table. It can be explained that the average score is in the interval class $94-98$, which means that $15.81 \%$ of the respondents' scores are at the average score, $43.16 \%$ are above the average score and $41.03 \%$ are above average score. Based on the results of testing, covariate analysis was obtained $(\mathrm{P}=0.002<$ 0.05). Thus, reject $\mathrm{HO}$ or accept Ha so that it is concluded that there is an effect of using the guided inquiry model, and conventional learning on Teacher's Self-Controlling on Virus material for Class X at UISU Medan Private High School.

The Influence of Learning Models on Teacher Self Controlling Anacova results using SPSS 22.0 show that the learning model has a significant effect on Teacher Self Controlling $(\mathrm{F}=7.54 ; \mathrm{P}=0.002)$ and pretest data correlates with post-test data on Teacher Self Controlling measurements $(\mathrm{F}=44.75 ; \mathrm{P}=0.000)$. Furthermore, the Tukey test results show that the value obtained in measuring the teacher's Self Controlling towards the learning outcomes of the 2 classes taught by the guided inquiry model $55.20 \pm 15.65\left(X^{-} \pm S B\right)$, was significantly higher than the control class taught with traditional learning $50.10 \pm 11.44\left(\mathrm{X}^{-} \pm \mathrm{SB}\right) \mathrm{score}$.

Table 1. Data Distribution of Score Variable Self Controlling

\begin{tabular}{cccccc}
\hline No. & & Interval Class & $\mathrm{f}_{\mathrm{i}}$ & $\mathrm{f}_{\mathrm{i} \text { relative }}$ \\
\hline 1 & 76 & - & 80 & 2 & 0,85 \\
2 & 81 & - & 85 & 2 & 0,85 \\
3 & 86 & - & 90 & 23 & 9,83 \\
4 & 91 & - & 95 & 74 & 31,62 \\
\hline
\end{tabular}




\begin{tabular}{cccccc}
\hline 5 & 96 & - & 100 & 37 & 15,81 \\
6 & 101 & - & 105 & 43 & 18,38 \\
7 & 106 & - & 110 & 33 & 14,10 \\
8 & 111 & - & 115 & 19 & 8,12 \\
9 & 116 & - & 120 & 1 & 0,43 \\
\hline Total & & & & 234 & 100 \\
\hline
\end{tabular}

Table 2. Data Distribution of Score Variable Self Controlling

\begin{tabular}{|c|c|c|}
\hline No. & Inquiry Test & Point \\
\hline 1 & Guided Inquiry & 55,20 \\
\hline 2 & Conventional & 50,10 \\
\hline
\end{tabular}

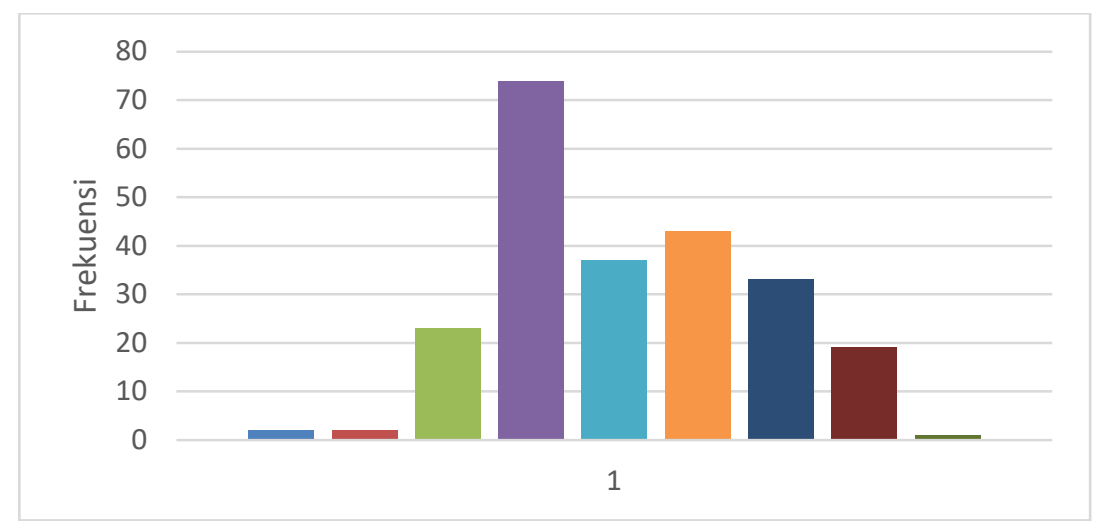

Figure 1. Histogram Image Score Variable Self Controlling

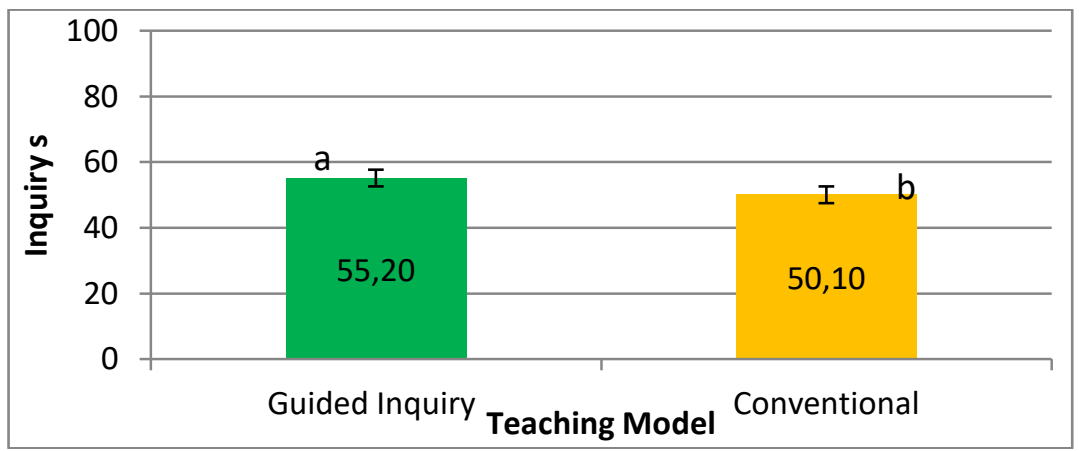

Figure 2. Figure of the Effect of Inquiry Learning Model on Self Controlling of Teacher X SMA Private UISU $(\mathrm{F}=7.54 ; \mathrm{P}=0.002)$

Self controlling is the ability to control one's own behavior, the ability to suppress and overcome impulsive behavior Self controlling is important for every human being, likewise a teacher, must have good selfcontrolling, not get used to being controlled by instincts, but must control it with a ratio, common sense and cleanliness of conscience. Every teacher has different self-controlling in solving his life problems, both those related to his personal problems and his work. Good self-controlling needs to be maintained by every teacher, because the teacher's job is related to many people, namely the principal, the vice principal, the teachers, administrative officers, laboratory assistants, librarians, students, and the parents of the students. students, a teacher is required to provide the best learning services that take place in the classroom. Teachers are responsible for providing learning services to their students, both learning services in the form of theory and practice. To be able to provide good service to all students, a teacher must have good knowledge, personality and self-controlling as well. With good self-controlling, a teacher can carry out his duties and responsibilities well and, this can be obtained if the teacher can think clearly and calmly, then behavior will be maintained and self-care will be maintained, and vice versa if the teacher does not having good selfcontrolling, it can have a bad impact because it can experience tension of thoughts and behave strangely. Teachers who do not have good self-controlling will be reflected in their attitude towards the environment 
around them, including in front of students. The negative behavior of the teacher will be a bad example for students and will indirectly affect the learning climate in the classroom and ultimately affect the learning outcomes obtained by students. Teachers who have good self-controlling use their feelings proportionally so that they can treat students objectively, but with compassion, not subjective feelings. Teachers who have good self-controlling will have a positive effect on the mental development of their students, and can be role models for students. Thus teachers who develop the potential of their intellect in carrying out their duties will provide the best for their students. A teacher who has good self-controlling, must have self-awareness and good self-management, with this personal competence, he will be able to adjust to the various problems he faces. Self controlling is reflected in the calm and wise behavior of teachers in making decisions. Being protective of students and fostering good relationships with each student and good at placing themselves either as teachers, friends or parents. Teachers with good self-controlling feel that teaching is an obligation and must be done wholeheartedly. The teacher teaches happily and tries to create a pleasant learning atmosphere in the classroom. Teaching activities become something fun and not a burden and in the end the teacher feels satisfaction with every job they do. From the description above it can be said that there is a need for good self-controlling for a teacher, it can be concluded that there is a relationship between selfcontrolling teachers and job satisfaction.

\section{Conclusion}

From the results of the study it can be concluded that: INQUIRY and Conventional in testing the value of Self Controlling Teachers on Virus Class X SMA Private UISU Medan. With a difference of 55.20 and 50.10 with a number of 5.0 at the level.

\section{References}

Anam, K. (2015). Pembelajaran Berbasis Inkuiri. Yogyakarta: Pustaka Pelajar.

Arikunto, S. (2012). Dasar-Dasar Evaluasi Pendidikan Edisi 2. Jakarta: Bumi Aksara.

Arikunto, S. (2012). Dasar-Dasar Evaluasi Pendidikan Edisi 2. Jakarta: Bumi Aksara.

Dimyati dan Mudjiono. (2006). Belajar dan Pembelajaran. Rineka Cipta: Jakarta.

Hamdani. (2011). Strategi Belajar Mengajar. Bandung: Pustaka Setia.

Hakim, T. (2008). Belajar Secara Efektif, Puspa Swara, Jakarta

Insar Damopolii , Aksamina M. Yohanita , N. Nurhidaya , M. Murtijani . (2018). Meningkatkan keterampilan proses sains dan hasil belajar siswa melalui pembelajaran berbasis inkuiri.Jurnal Bioedukatika Vol. 6 No. 1 Tahun 201822 - 30

Kuhlthau, C.C. (2010). Guided Inquiry: School Libraries in the 21st Century. School Libraries Worldwide. 16 (1): $17-28$.

Nurmayani J.Said, A.J. Patandean, Muhammad Aqil Rusli. (2017). Peranan Model Pembelajaran Inkuiri Terbimbing Terhadap Keterampilan Proses Sains Pada Peserta Didik Kelas X SMA Negeri 2 Polewali, Jurnal Sains dan Pendidikan Fisika (JSPF) Jilid 13, Nomor 1. ISSN Cetak: 1858-330X dan ISSN Online: 2548-6373.

Muhidin, S. A. dan M. Abdurrahman. (2009). Analisis Korelasi Regresi dan Jalur Dalam Penelitian (Dilengkapi Aplikasi Program SPSS). Bandung: Pustaka Setia.

Paidi. (2007). Peningkatan Scientific Skill Siswa Melalui Implementasi Metode Guided Inquiry Pada Pembelajaran Biologi di SMAN 1 Sleman. Yogyakarta: FMIPA Universitas Negeri Yogyakarta

Riska Fitriyani, Sri Haryani dan Eko Budi Susatyo, (2017). Pengaruh Model Inkuiri Terbimbing Terhadap Keterampilan Proses Sains Pada Materi Kelarutan Dan Hasil Kali KelarutanJurnal Inovasi Pendidikan Kimia, Vol. 11, No. 2, 2017, halaman 1957 - 1970.

Rostika, Nurfine Dwi, (2012). Penerapan Model Inkuiri Terbimbing Terhadap Keterampilan Proses Sains Pada Konsep Ekosistem Di Smp Negeri 2 Ciledug, Skripsi: Fakultas Tarbiyah Institut Agama Islam Negeri (IAIN) Syekh Nurjati Cirebon. 